\title{
PRESISI PENGUKURAN PRODUK SAMPING TAMBANG TIMAH NUDUR MENGGUNAKAN ANALISIS XRF DAN PELUANG EKONOMI PRODUKNYA
}

\author{
Measurement Precision of Nudur Tin By-Products Using XRF Analysis \\ and Their Economic Opportunities
}

\author{
RONALDO IRZON ${ }^{1}$, KURNIA ${ }^{1}$, dan AGUS D. HARYANTO ${ }^{2}$ \\ 1 Pusat Survei Geologi \\ Jalan Diponegoro 57 Bandung, \\ e-mail : ronaldoirzon18@gmail.com \\ ${ }^{2}$ Fakultas Teknik Geologi Universitas Padjadjaran \\ Jalan Raya Bandung Sumedang KM 21, Jatinangor
}

\begin{abstract}
ABSTRAK
Penambangan timah hasil intrusi granit tipe-S di Pulau Bangka yang dimulai sejak periode kolonial Belanda menghasilkan produk samping. Presisi, akurasi, dan reproduktivitas dibutuhkan untuk memverifikasi hasil pengukuran perangkat analisis yang memang diperlukan dalam perkembangan ilmu kebumian. Perangkat $X$-ray fluorescence pada umumnya diaplikasikan untuk mengukur kandungan oksida utama dan beberapa unsur jejak yang memiliki kelimpahan tinggi. Presisi pengukuran oksida utama, unsur jejak, berikut logam tanah jarang pada percontoh produk samping penambangan timah milik PT Timah di Nudur, Pulau Bangka, menggunakan XRF adalah tujuan penelitian ini. Informasi mengenai manfaat ekonomis material sisa penambangan tersebut juga dapat diketahui melalui studi ini sehingga dapat menjadi landasan kebijakan bagi pemerintah maupun PT Timah. Seluruh analit terbukti presisi berdasarkan prinsip RSD <2/3 kali RSDHorwitz, kecuali MgO, CaO, Mo, Cr, dan Zn. Bahan sisa penambangan ini masih cukup ekonomis. Terdapat indikasi awal bahwa titanit dan malayait hadir bersama pada granit pembawa timah di Nudur berdasarkan komposisi geokimia percontoh yang dipelajari.
\end{abstract}

Kata kunci: presisi, produk samping, tambang timah, geokimia.

\begin{abstract}
Mining tin deposit of S-type granite intrusion in Bangka Island has been started since the Dutch colonial period and naturally produces by-products. Precision, accuracy, and reproducibility are needed to verify the measurement results of the analytical instruments that are needed in the development of earth science. X-ray fluorescence is generally applied to measure the major oxides and some abundant trace elements compositions. Precision measurement of the major oxides, trace elements, and REEs in the by-products samples of PT Timah tin mining in Nudur, Bangka Island using the XRF is the purpose of this study. Information regarding the economic benefits of the sample can also be predicted through this study to be used as the basis for the government and PT Timah for its economic policy. Almost all analytes attain high precision based on the RSD <2/3 times RSDHorwitz principle, except for MgO, CaO, Mo, Cr, and $\mathrm{Zn}$. The mine's by-product material is still economical. Titanite and malayaite might be present together in the tin-bearing granites of Nudur based on the analyzed geochemical composition of the samples.
\end{abstract}

Keywords: precision, by-product, tin mining, geochemistry. 


\section{PENDAHULUAN}

Perangkat pengukuran kadar geokimia sangat dibutuhkan dalam pengembangan ilmu kebumian. Tanpa perangkat analisis, para peneliti hanya akan terpaku pada interpretasi megaskopis berikut korelasi antar batuan. Secara umum, data geokimia dapat diklasifikasikan dalam beberapa kelompok, yaitu oksida utama, unsur jejak, logam tanah jarang (LTJ), golongan platina dan isotop. Penafsiran data oksida utama dan unsur jejak terlebih dahulu dikembangkan dengan beberapa pilihan perangkat analisis, seperti $X$ ray fluoresence (XRF), instrumental neutron activation analysis (INAA), dan analisis kimia basah (Frierdich, Hasenmueller dan Catalano, 2011; Hunt dkk., 2015; Irzon dan Kurnia, 2015; Usman, 2016) Inductively coupled plasma-mass spectrometer (ICP-MS), yang terkadang dapat dipadukan dengan laser ablasi, diperlukan pada studi sebelumnya (Irzon dan Kurnia, 2014; Irzon dkk., 2019) untuk mengukur komposisi logam tanah jarang dan golongan platina, karena tingkat ketelitiannya yang tinggi hingga ppb (part per billion). Lebih jauh, ICP-MS dapat dipadukan dengan laser ablasi untuk meningkatkan limit deteksi pengujian (Nadoll dan Koenig, 2011; Ubide $d k k ., 2015)$. Pada studi ilmu kebumian, uji isotop biasanya berkorelasi dengan penarikhan percontoh batuan. Terdapat beberapa opsi mengenai pengukuran isotop, yaitu multi-collector thermal ionisation mass spectrometer (TIMS), secondary ion mass spectrometry (SIMS), dan multicollectorinductively coupled plasma mass spectrometer (MC-ICP-MS) seperti telah dimanfaatkan oleh Lin $d k k$. (2014).

Presisi, akurasi, dan reproduktivitas dibutuhkan dalam bidang ilmu pengetahuan, industri rekayasa, dan statistik untuk menilai suatu sistem analisis. Presisi atau ketelitian adalah ukuran yang menunjukkan derajat kesesuaian antara hasil uji individual yang dilaksanakan secara berulang pada percontoh homogen (Harmita, 2004; Asmariani, Amriani dan Haslianti, 2017). Bahan acuan standar dibutuhkan untuk mengetahui derajat akurasi atau kecermatan yang dinyatakan sebagai kedekatan hasil uji terhadap nilai sertifikasi bahan standar. Oleh sebab itu, kemurnian, kesesuaian terhadap matriks percontoh, dan ketepatan preparasi bahan acuan standar secara tidak langsung berpengaruh terhadap tingkat akurasi (Xie dkk., 2010; Nadoll dan Koenig, 2011; Irzon dan Kurnia, 2015, 2019). Reproduktivitas atau juga disebut ketertiruan adalah keseksamaan metode jika dikerjakan pada kondisi yang berbeda. Biasanya analisis reproduktivitas dilakukan menggunakan laboratorium, peralatan, pereaksi, pelarut, dan analis yang berbeda (Harmita, 2004; Ubide $d k k ., 2015 ;$ Asmariani, Amriani dan Haslianti, 2017; Irzon dan Kurnia, 2019).

Provinsi Kepulauan Bangka Belitung merupakan wilayah yang kaya akan sumber daya alam dengan lebih dari 850 izin usaha pertambangan (IUP) logam dan non logam (Gambar 1). Tambang timah Nudur dimiliki oleh PT Timah, yang secara administratif berada dalam wilayah Kabupaten Bangka Selatan. Mineralisasi timah di Pulau Bangka berkorelasi dengan granit Mandala Tengah di Asia Tenggara yang bertipe-S dan diperkirakan terbentuk pada zaman Trias Akhir (Irzon, 2015; Usman, 2016; Ng dkk., 2017). Penambangan timah di pulau ini telah dimulai sejak zaman kolonial Belanda dan tersebar di berbagai lokasi. Produk samping pertambangan timah adalah bagian sisa target mineral atau bahan yang ingin diperoleh dan disebut juga sebagai ampas (tailing). Beragam masalah lingkungan dan kesehatan bagi penduduk sekitar yang dapat ditimbulkan oleh ampas timah telah dibahas beberapa studi sebelumnya (Ashraf, Maah dan Yusoff, 2011; Irzon dkk., 2018). Namun demikian, beberapa bahan yang bernilai ekonomis terbukti masih terkandung dalam ampas timah (Irzon dan Kurnia, 2014; Hamzah, Mardhiansyah dan Firdaus, 2018; Purwadi, van der Werff dan Lievens, 2019), sehingga dapat menjadi peluang bagi pengusaha pertambangan dan pemerintah setempat. 


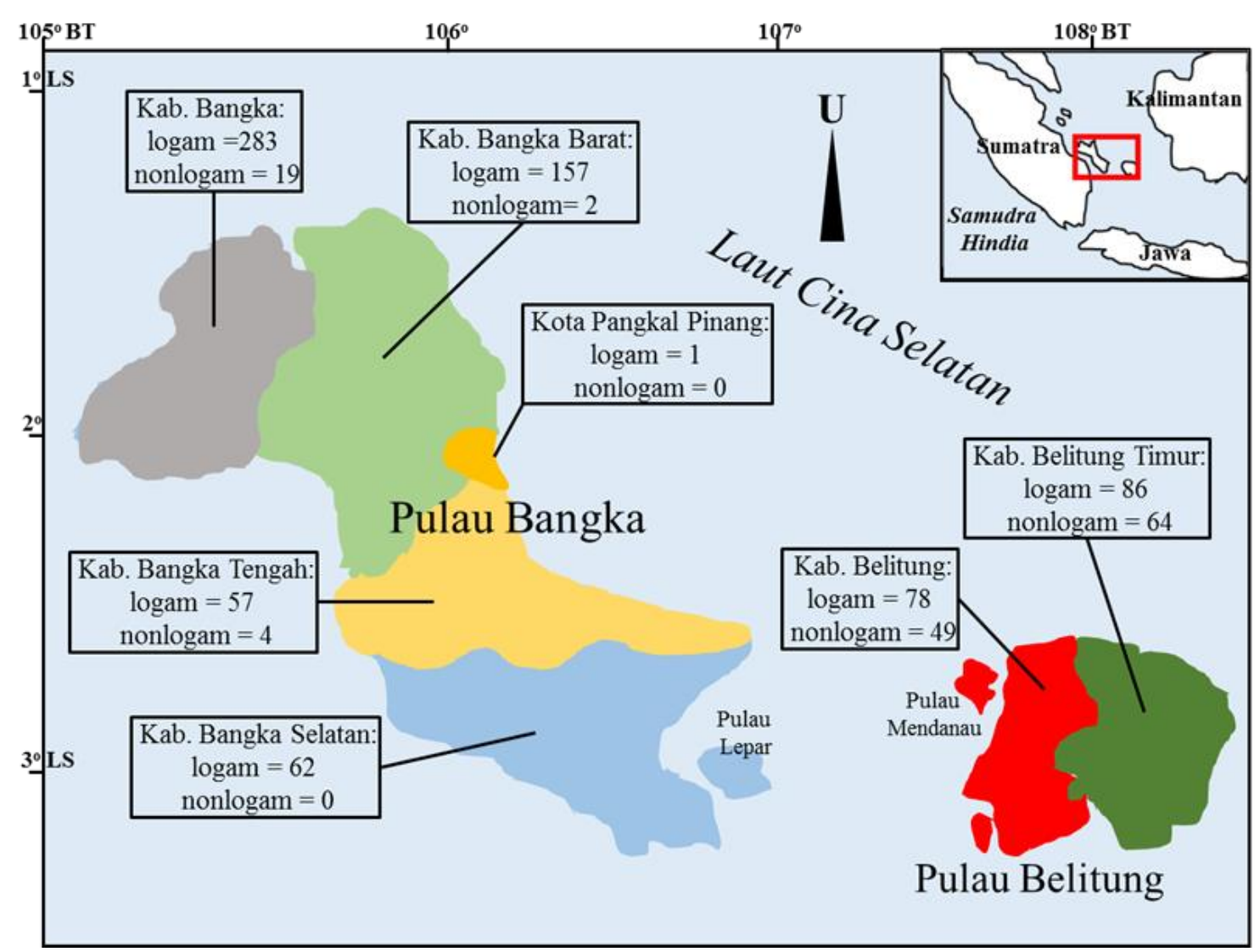

sumber: Arumingtyas (2018)

Gambar 1. Sebaran IUP pada masing-masing kabupaten di Provinsi Kepulauan Bangka Belitung

\section{TATANAN GEOLOGIS}

Pulau Bangka berada di timur Pulau Sumatra, pada wilayah Kepulauan Provinsi Bangka Belitung. Pulau ini dikategorikan sebagai salah satu pulau timah bersama dengan Pulau Belitung, Singkep, dan Kundur (Cobbing, 2005; Irzon dan Kurnia, 2014; Irzon, 2015; Irzon $d k k$., 2018). Tambang timah Nudur berada di Kecamatan Air Gegas, pada Peta Geologi Lembar Bangka Selatan (Margono, Supandjono dan Partoyo, 1995) yang terdiri dari batuan malihan, batuan terobosan, dan endapan permukaan serta sedimen seperti dapat dilihat pada Gambar 2. Kompleks Malihan Pemali merupakan batuan malihan berumur Perem di selatan Pulau Bangka, yang terdiri dari filit, sekis dan kuarsit. Batuan intrusif hanya terdiri dari Granit Klabat yang diperkirakan membeku pada zaman Yura dengan ragam granit biotit, granodiorit, dan granit genesan (Margono, Supandjono dan Partoyo, 1995). Meskipun demikian, Ng dkk. (2017) mengelompokkan granit di selatan Pulau Bangka menjadi tiga pluton, yaitu Pading, Toboali, dan Nama. Percontoh yang dipelajari berada dalam domain granit Toboali yang terbekukan 204 juta tahun yang lalu (Ng $d k k$., 2017). Formasi Tanjung Genting, Formasi Ranggam, Endapan Rawa dan Aluvium adalah runtunan satuan batuan sedimen dari tua ke muda. Formasi Tanjung Genting yang dominan pada peta geologi ini diperkirakan tersedimentasi pada waktu Trias, sedangkan Formasi Ranggam yang terkonsentrasikan di timur laut Pulau Bangka pada kala MiosenPliosen. Kemudian, Endapan Rawa dan Aluvium terbentuk pada kala Holosen (Margono, Supandjono dan Partoyo, 1995). 


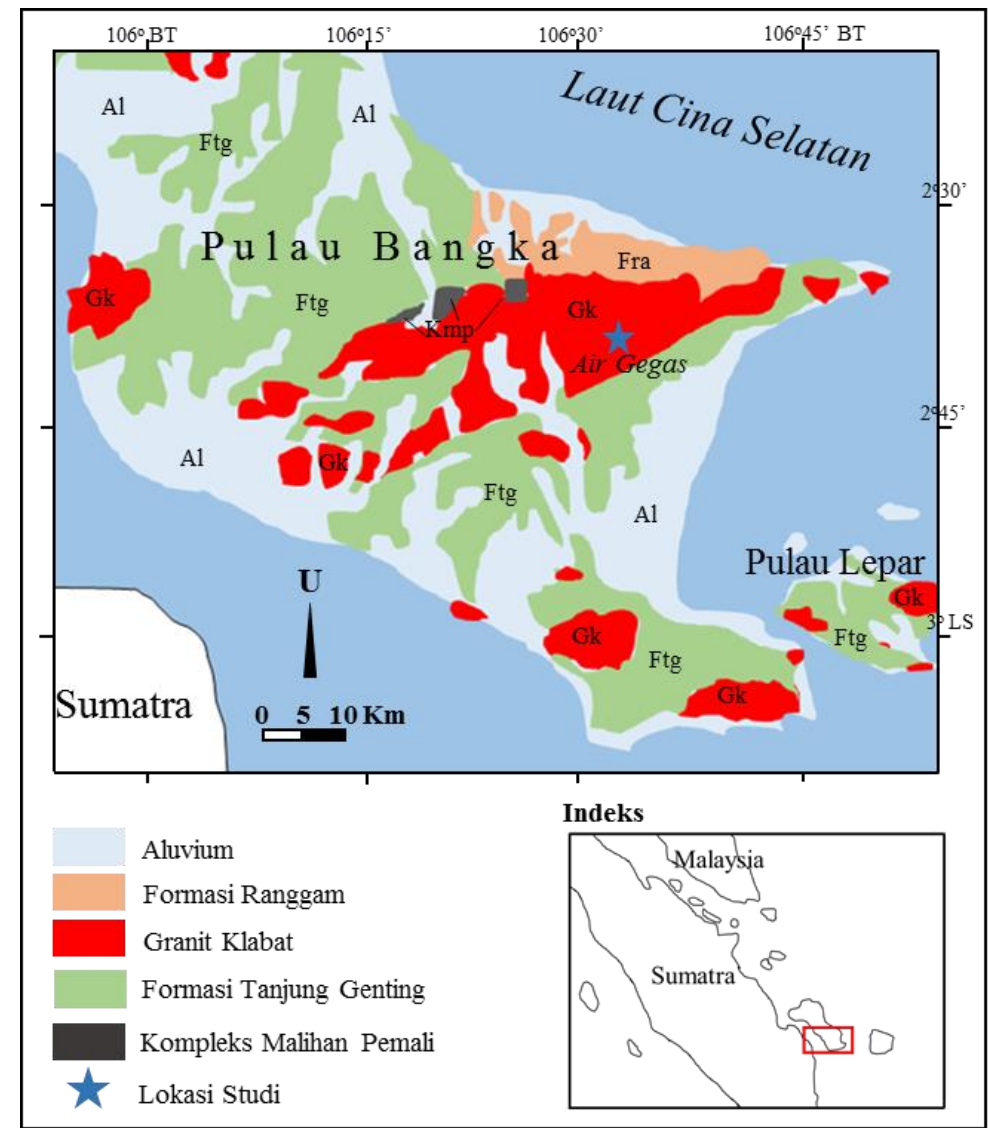

sumber: Margono, Supandjono dan Partoyo (1995)

Gambar 2. Lokasi tambang timah Nudur dalam Peta Geologi Lembar Bangka Selatan.

\section{METODE}

\section{Deskripsi Percontoh}

Batuan granitik pembawa timah yang telah ditambang dipisahkan dari pengotornya menggunakan meja goyang (shaking table). Aliran air dimanfaatkan untuk mempermudah proses pemisahan secara gravimetri tersebut. Pada lokasi pengambilan percontoh, beberapa personal juga difungsikan untuk membuang bahan pengotor berupa kerikil dari meja goyang secara manual. Tahap berikutnya adalah flotasi, yaitu pemisahan timah berdasarkan sifat permukaannya. Percontoh BKRK-06 yang dipelajari merupakan produk samping dari proses akhir pemisahan timah di lapangan berupa pasir berbutir halus-sedang dan berwarna kehitaman. Sekitar $5 \mathrm{~kg}$ produk samping tersebut diambil untuk dipreparasi di laboratorium. Kondisi di Tambang Nudur dapat dilihat pada Gambar 3a. PT Timah sendiri telah membuat kebijakan untuk tidak langsung membuang percontoh ini dan disimpan dalam tumpukan karung di lokasi khusus (Gambar 3b).

\section{Analisis Geokimia}

Seluruh preparasi dan pengukuran kadar geokimia pada percontoh dilaksanakan di Laboratorium Pusat Survei Geologi. Percontoh yang diperoleh dari kegiatan lapangan dikeringkan di bawah terik matahari selama satu hari tanpa pencucian. Meski telah berukuran pasiran, percontoh tetap digerus dan diayak untuk memperoleh ukuran butir seragam lolos 200 mesh. Homogenisasi percontoh dilaksanakan manual yaitu digelindingkan dalam tong selama setidaknya 24 jam atau tiga hari kerja. Percontoh kemudian dibagi ke dalam empat split (bagian) dan disimpan dalam wadah yang terbuat dari kaca. Perlu diperhatikan bahwa wadah dari logam harus dihindari pada studi ini karena dapat menyebabkan ketidakhomogenan percontoh selama penyimpanan akibat magnetisme. 


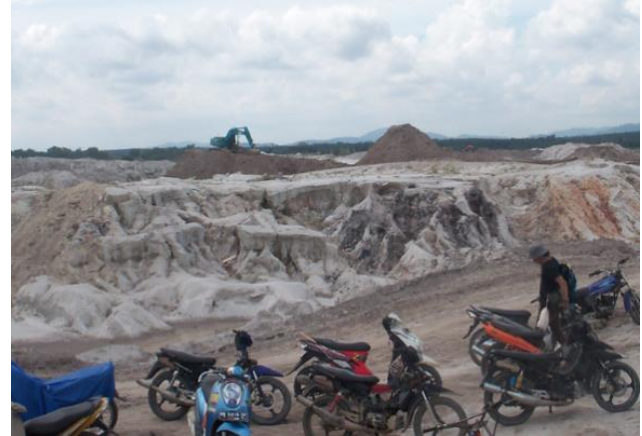

(a)

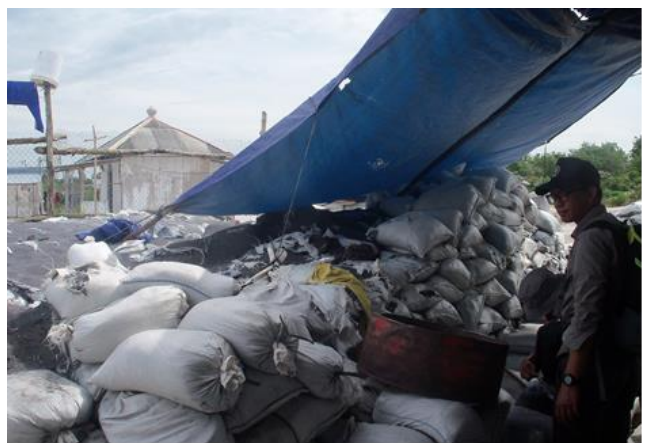

(b)

Gambar 3. a) Kondisi wilayah tambang PT Timah di Nudur, dan b) Produk samping penambangan di lokasi studi berupa pasir berwarna kehitaman yang sebagian telah disimpan dalam karung.

Perangkat analisis kadar percontoh pada studi ini adalah X-ray fluorescence (XRF) yang menggunakan prinsip pemantulan dan penyerapan radiasi sinar-X (Irzon dan Kurnia, 2015, 2019). Total delapan percontoh yang terdiri dari masing-masing dua sub-percontoh pada empat wadah penyimpanan ditimbang dan dipreparasi sesuai prosedur Irzon $d k k$. (2018). Meskipun membutuhkan tambahan karboksi metil selulosa sebagai bahan pengikat, metode pressed pellet dipilih pada studi ini selain glass disk yang rentan terhadap keterdapatan pengotor. Ukuran butir yang semakin kecil akan memberikan hasil analitik yang lebih baik karena meningkatkan homogenitas pelet (pellet) ketika dimampatkan menggunakan mesin kompresi hidrolik. Kemudian, ketebalan pelet juga dibuat tidak kurang dari ketebalan ring stainless steel karena dapat memengaruhi hasil analisis juga. Karakter radiasi hasil pemantulan sinar-X pada percontoh akan terdeteksi keliru pada pelet yang tipis (Gambar 4). Urutan preparasi percontoh produk samping tambang timah di Nudur tersaji pada Gambar 5.
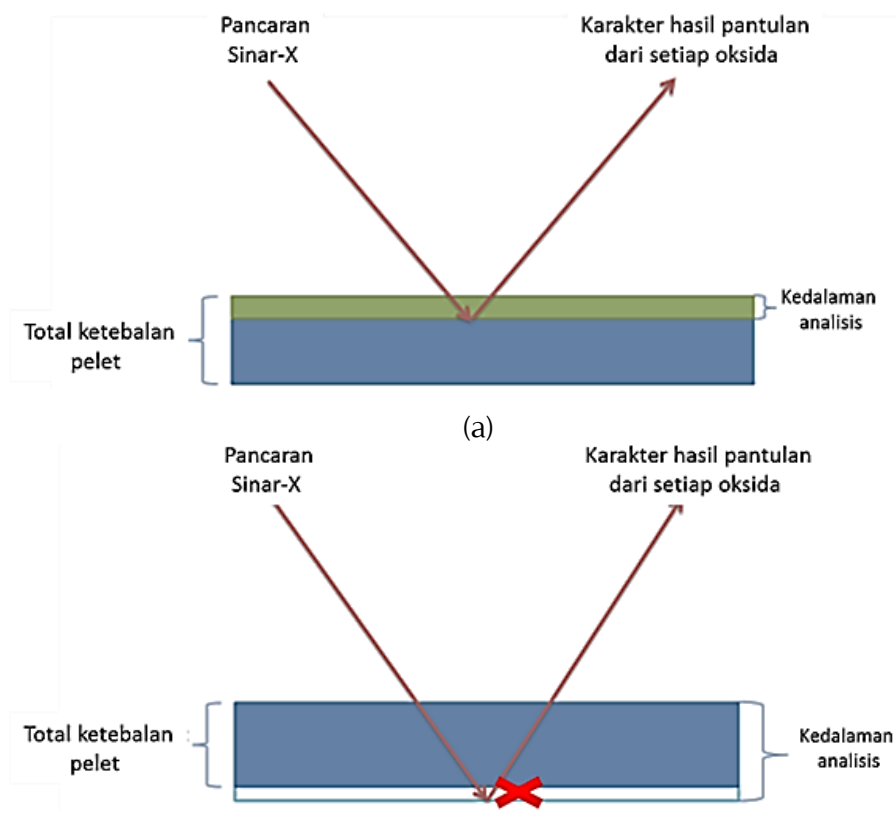

(b)

Gambar 4. a) Ketebalan pelet yang cukup sehingga menghasilkan hasil analisis percontoh yang sesuai; b) Kesalahan pengukuran dapat diakibatkan oleh pembuatan pelet yang kurang tebal. 


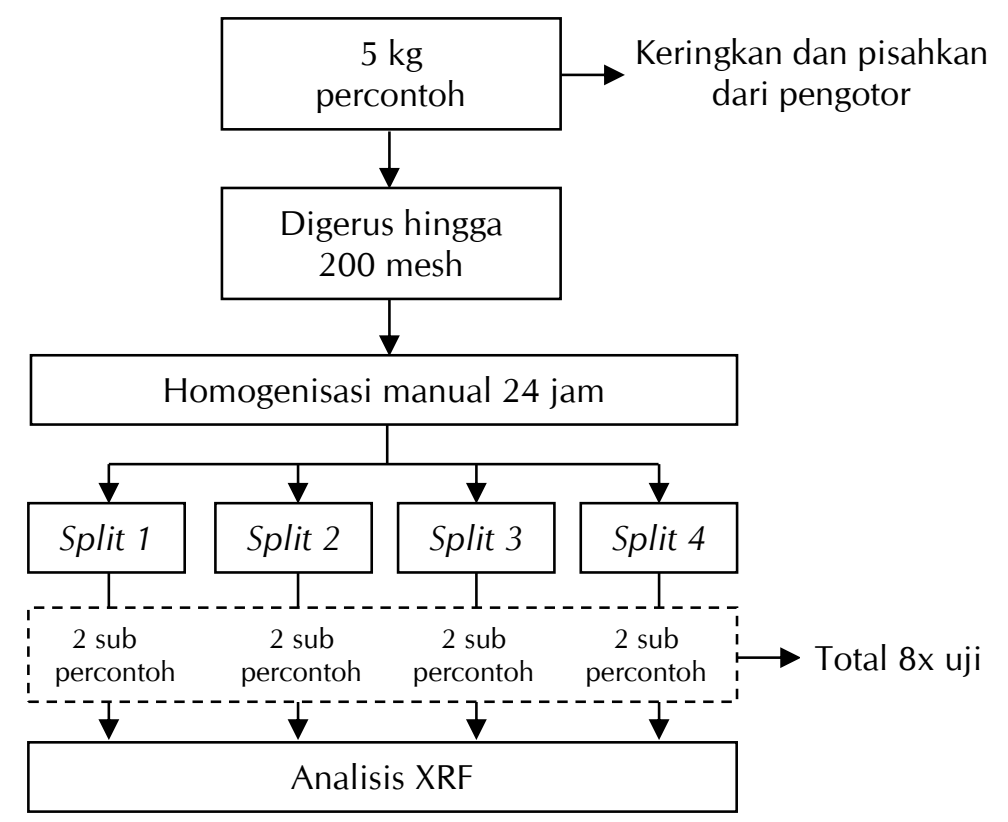

Gambar 5. Urutan preparasi percontoh sebelum dianalisis menggunakan XRF

\section{HASIL DAN PEMBAHASAN}

Perangkat XRF mengeluarkan hasil analisis kadar percontoh berupa oksida unsur kimia. Oleh karena itu, kadar unsur dapat diketahui dengan perkalian hasil analisis XRF terhadap rasio nomor massa dan nomor massa oksidanya. Seluruh hasil analisis berikut perolehan konversi oksida unsur jejak dan LTJ menjadi kadar unsur tertera pada Tabel $1 . \mathrm{TiO}_{2}$ dan $\mathrm{Fe}_{2} \mathrm{O}_{3 \mathrm{~T}}$ merupakan dua oksida utama dengan kelimpahan terbesar dengan rerata 51,69\% dan $22,75 \%$ secara berurutan. Meskipun rerata $\mathrm{SiO}_{2}, \mathrm{MnO}, \mathrm{Al}_{2} \mathrm{O}_{3}$, dan $\mathrm{P}_{2} \mathrm{O}_{5}$ terdeteksi $>1 \%$, oksida utama lain $<1 \%$. Percontoh yang diteliti masih memiliki rerata kadar zirkon, serium, dan timah yang cukup tinggi, yaitu 5,06\%, 1,40\%, dan $1,08 \%$ secara berurutan. Perangkat XRF tidak dispesifikasikan untuk analisis percontoh dengan tingkat ketelitian tinggi seperti halnya ICP-MS (Nadoll dan Koenig, 2011; Ubide $d k k$., 2015; Irzon dan Abdullah, 2016; Irzon, 2017; Irzon $d k k ., 2019)$. Oleh sebab itu, beberapa elemen LTJ yang tidak terdeteksi pada penelitian ini sangat mungkin terkait dengan spesifikasi XRF.

\section{Presisi Pengukuran}

Presisi berkorelasi dengan homogenitas percontoh karena derajat homogenitas terbaik menghasilkan distribusi analit maupun partikel yang merata pada seluruh bagian percontoh, sehingga terbaca sama melalui pengulangan pengukuran. Derajat presisi dapat disimpulkan melalui kalkulasi RSD (relative standard deviation, simpangan baku relatif) dan

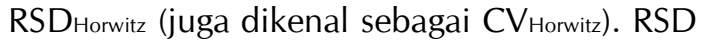
diketahui sebagai rasio standar deviasi (SD) terhadap rerata $\left(\mathrm{X}_{\mathrm{R}}\right)$ dan dihitung dengan menggunakan persamaan (1)-(3) berikut:

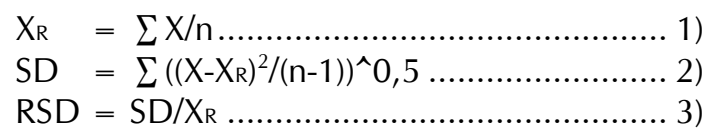

dengan $X_{R}, n, S D$, dan RSD secara berturutturut adalah rerata, jumlah pengukuran, standar deviasi, dan simpangan baku relatif. Kemudian, RSDHorwitz dikalkulasi menggunaan persamaan (4), yaitu:

$\mathrm{RSD}_{\text {Horwitz }}=2^{\wedge}\left(1-\left(0,5 \times \log \mathrm{X}_{\mathrm{R}}\right)\right)$

Hasil perhitungan RSD dan RSD Horwitz dapat dicermati pada Tabel 1.

Para peneliti sebelumnya telah mengungkapkan bahwa rangkaian pengukuran dianggap memiliki tingkat presisi tinggi, jika nilai RSD yang dihasilkan lebih kecil dari nilai 2/3 RSD Horwitz (Taufiq, Hutagaol dan Pramono, 2011; Asmariani, Amriani dan Haslianti, 2017). Berdasarkan konsep Horwitz tersebut dapat disimpulkan bahwa hampir seluruh analit mempunyai derajat presisi yang baik, 
kecuali $\mathrm{MgO}, \mathrm{CaO}, \mathrm{Mo}, \mathrm{Cr}$, dan $\mathrm{Zn}$ seperti dapat tampak pada Gambar 6. Derajat homogenisasi juga dapat dipengaruhi oleh proses pengemasan. Perlu diperhatikan untuk tidak memilih kemasan percontoh yang dapat menyebabkan terjadinya reaksi percontoh terhadap lingkungan dan kemasan seperti bahan dari kayu. Kemudian, derajat ketidakhomogenan dapat diperkecil dengan penggunaan beberapa teknik seperti penggunaan pengaduk magnetis, V-blenders, perpaduan stirrer dan propeller, teknik rolling/sheet mixing, dan ball-rod mill homogenization (Miao dkk., 2011; Haq dkk., 2018). Metode terakhir tersedia di Laboratorium Pusat Survei Geologi, sehingga dapat diaplikasikan pada studi ini. Metode uji ini dapat dipertajam lebih jauh, baik dengan penggunaan perangkat yang dispesifikasikan untuk analisis LTJ (ICP-MS dan INAA) maupun pengujian bahan acuan standar.

Tabel 1. Hasil pengukuran percontoh produk samping tambang timah di Nudur: a) Oksida utama dan unsur jejak; dan b) Unsur tanah jarang

a)

\begin{tabular}{|c|c|c|c|c|c|c|c|c|c|c|c|}
\hline \multirow{2}{*}{ Kadar } & \multicolumn{2}{|c|}{ Botol 1} & \multicolumn{2}{|c|}{ Botol 2} & \multicolumn{2}{|c|}{ Botol 3} & \multicolumn{2}{|c|}{ Botol 4} & \multirow{2}{*}{ Rerata } & \multirow{2}{*}{ RSD } & \multirow{2}{*}{ RSD Horwitz } \\
\hline & $\mathrm{A}$ & $\mathrm{B}$ & A & $\mathrm{B}$ & A & $\mathrm{B}$ & A & B & & & \\
\hline \multicolumn{12}{|c|}{ Oksida Utama (\%) } \\
\hline $\mathrm{SiO}_{2}$ & 5,88 & 5,96 & 5,94 & 5,94 & 5,97 & 6,05 & 6,04 & 5,96 & 5,97 & 0,93 & 6,11 \\
\hline $\mathrm{TiO}_{2}$ & 51,68 & 51,71 & 51,54 & 51,72 & 51,73 & 51,61 & 51,62 & 51,69 & 51,66 & 0,13 & 4,42 \\
\hline $\mathrm{Al}_{2} \mathrm{O}_{3}$ & 1,03 & 1,03 & 0,99 & 1,02 & 0,99 & 1,04 & 1,03 & 1,03 & 1,02 & 1,74 & 7,98 \\
\hline $\mathrm{Fe}_{2} \mathrm{O}_{3} \mathrm{~T}$ & 22,71 & 22,85 & 22,77 & 22,75 & 22,82 & 22,72 & 22,65 & 22,75 & 22,75 & 0,28 & 5,00 \\
\hline $\mathrm{MnO}$ & 2,36 & 2,38 & 2,37 & 2,39 & 2,38 & 2,36 & 2,37 & 2,37 & 2,37 & 0,44 & 7,02 \\
\hline $\mathrm{MgO}$ & 0,07 & 0,09 & 0,10 & 0,09 & 0,07 & 0,07 & 0,09 & 0,07 & 0,08 & 9,92 & 11,68 \\
\hline $\mathrm{CaO}$ & 0,01 & 0,01 & 0,01 & 0,01 & 0,01 & 0,01 & 0,02 & 0,01 & 0,01 & 24,14 & 16,31 \\
\hline $\mathrm{P}_{2} \mathrm{O}_{5}$ & 1,52 & 1,51 & 1,43 & 1,50 & 1,47 & 1,47 & 1,44 & 1,48 & 1,48 & 2,16 & 7,54 \\
\hline \multicolumn{12}{|c|}{ Unsur Jejak (ppm) } \\
\hline $\mathrm{Nb}_{2} \mathrm{O}_{5}$ & 2.670 & 2.720 & 2.720 & 2.690 & 2.710 & 2.690 & 2.660 & 2.690 & 2.694 & & \\
\hline $\mathrm{Nb}$ & 21.22 & 2.162 & 2.162 & 2.138 & 2.154 & 2.138 & 2.114 & 2.138 & 2.141 & 0,82 & 10,09 \\
\hline $\mathrm{ZrO}_{2}$ & 69.100 & 66.500 & 70.100 & 68.000 & 67.400 & 68.300 & 68.800 & 69.000 & 68.400 & & \\
\hline $\mathrm{Zr}$ & 51.123 & 49.199 & 51.863 & 50.309 & 49.865 & 50.531 & 50.901 & 51.049 & 50.605 & 1,62 & 6,27 \\
\hline $\mathrm{SnO}_{2}$ & 13.800 & 13.600 & 13.800 & 13.600 & 13.900 & 13.800 & 14.200 & 13.500 & 13.775 & & \\
\hline Sn & 10.875 & 10.718 & 10.875 & 10.718 & 10.954 & 10.875 & 11.191 & 10.639 & 10.856 & 1,59 & 7,9 \\
\hline $\mathrm{V}_{2} \mathrm{O}_{5}$ & 1.800 & 1.830 & 1.820 & 1.850 & 1.880 & 1.840 & 1.810 & 1.820 & 1.831 & & \\
\hline V & 1.009 & 1.026 & 1.020 & 1.037 & 1.054 & 1.031 & 1.014 & 1.020 & 1.026 & 1,38 & 11,27 \\
\hline $\mathrm{HfO}_{2}$ & 1080 & 1100 & 1100 & 1090 & 1110 & 1180 & 1100 & 1120 & 1110 & & \\
\hline $\mathrm{Hf}$ & 916 & 933 & 933 & 924 & 941 & 1001 & 933 & 950 & 941 & 2,77 & 11,42 \\
\hline $\mathrm{PbO}$ & 557 & 576 & 565 & 579 & 595 & 595 & 605 & 597 & 584 & & \\
\hline $\mathrm{Pb}$ & 517 & 535 & 524 & 537 & 552 & 552 & 562 & 554 & 542 & 2,92 & 12,41 \\
\hline $\mathrm{MoO}_{3}$ & 387 & 395 & 254 & 385 & 468 & 366 & 392 & 457 & 388 & & \\
\hline Mo & 258 & 263 & 169 & 257 & 312 & 244 & 261 & 305 & 259 & 16,78 & 13,87 \\
\hline $\mathrm{Cr}_{2} \mathrm{O}_{3}$ & 310 & 274 & 334 & 311 & 339 & 311 & 233 & 332 & 306 & & \\
\hline $\mathrm{Cr}$ & 212 & 187 & 229 & 213 & 232 & 213 & 159 & 227 & 209 & 11,71 & 14,32 \\
\hline $\mathrm{Ga}_{2} \mathrm{O}_{3}$ & 124 & 115 & 110 & 123 & 124 & 119 & 108 & 120 & 118 & & \\
\hline Ga & 92 & 85 & 82 & 91 & 92 & 88 & 80 & 89 & 87 & 5,32 & 16,33 \\
\hline $\mathrm{ZnO}$ & 120 & 134 & 120 & 340 & 133 & 132 & 150 & 142 & 159 & & \\
\hline $\mathrm{Zn}$ & 96 & 108 & 96 & 273 & 107 & 106 & 120 & 114 & 127 & 21,51 & 15,67 \\
\hline $\mathrm{ThO}_{2}$ & 3.300 & 3.350 & 3.350 & 3.360 & 3.290 & 3.280 & 3.270 & 3.290 & 3.311 & & \\
\hline Th & 2.900 & 2.944 & 2.944 & 2.953 & 2.891 & 2.882 & 2.874 & 2.891 & 2.910 & 1,09 & 9,63 \\
\hline $\mathrm{U}_{3} \mathrm{O}_{8}$ & 339 & 329 & 336 & 322 & 337 & 338 & 343 & 320 & 333 & & \\
\hline U & 287 & 279 & 285 & 273 & 286 & 287 & 291 & 271 & 282 & 2,52 & 13,69 \\
\hline
\end{tabular}


b)

\begin{tabular}{|c|c|c|c|c|c|c|c|c|c|c|c|}
\hline \multirow[t]{2}{*}{ Kadar } & \multicolumn{2}{|c|}{ Botol 1} & \multicolumn{2}{|c|}{ Botol 2} & \multicolumn{2}{|c|}{ Botol 3} & \multicolumn{2}{|c|}{ Botol 4} & \multirow{2}{*}{ Rerata } & \multirow{2}{*}{ RSD } & \multirow{2}{*}{ RSD Horwitz } \\
\hline & A & $B$ & $A$ & $B$ & $A$ & $B$ & A & $B$ & & & \\
\hline \multicolumn{12}{|c|}{ Unsur Tanah Jarang } \\
\hline $\mathrm{SC}_{2} \mathrm{O}_{3}$ & 59 & 54 & 72 & 57 & 60 & 57 & 64 & 38 & 58 & & \\
\hline Sc & 38 & 35 & 47 & 37 & 39 & 37 & 42 & 25 & 38 & 16,77 & 37,08 \\
\hline $\mathrm{Y}_{2} \mathrm{O}_{3}$ & 5.700 & 5.790 & 5.820 & 5.800 & 5.700 & 5.840 & 5.760 & 5.760 & 5.771 & & \\
\hline Y & 4.489 & 4.560 & 4.584 & 4.568 & 4.489 & 4.600 & 4.537 & 4.537 & 4.545 & 0,9 & 18,02 \\
\hline $\mathrm{La}_{2} \mathrm{O}_{3}$ & 6.550 & 6.500 & 6.490 & 6.650 & 6.510 & 6.410 & 6.400 & 6.520 & 6.504 & & \\
\hline $\mathrm{La}$ & 5.586 & 5.543 & 5.534 & 5.671 & 5.551 & 5.466 & 5.458 & 5.560 & 5.546 & 1,21 & 17,48 \\
\hline $\mathrm{CeO}_{2}$ & 15.900 & 15.900 & 15.600 & 15.400 & 15.400 & 15.500 & 15.600 & 15.500 & 15.600 & & \\
\hline $\mathrm{Ce}$ & 14.269 & 14.269 & 14.000 & 13.821 & 13.821 & 13.910 & 14.000 & 13.910 & 14.000 & 1,28 & 15,21 \\
\hline $\mathrm{Pr}_{6} \mathrm{O}_{11}$ & 780 & 680 & 580 & 760 & 700 & 810 & 530 & 540 & 673 & & \\
\hline $\operatorname{Pr}$ & 646 & 563 & 480 & 629 & 579 & 671 & 439 & 447 & 557 & 16,42 & 24,71 \\
\hline $\mathrm{Nd}_{2} \mathrm{O}_{3}$ & 5.740 & 5.400 & 5.700 & 5.750 & 5.550 & 5.870 & 5.620 & 5.460 & 5.636 & & \\
\hline $\mathrm{Nd}$ & 4.920 & 4.629 & 4.886 & 4.929 & 4.757 & 5.031 & 4.817 & 4.680 & 4.831 & 2,82 & 17,85 \\
\hline $\mathrm{DyO}_{3}$ & 400 & 602 & 524 & 511 & 564 & 604 & 563 & 573 & 543 & & \\
\hline Dy & 309 & 465 & 405 & 394 & 435 & 466 & 435 & 442 & 419 & 6,24 & 25,68 \\
\hline $\mathrm{ErO}_{3}$ & 640 & 556 & 637 & 619 & 635 & 648 & 557 & 570 & 608 & & \\
\hline $\mathrm{Er}$ & 497 & 432 & 495 & 481 & 493 & 503 & 433 & 443 & 472 & 6,54 & 25,33 \\
\hline $\mathrm{Yb}_{2} \mathrm{O}_{3}$ & 558 & 557 & 544 & 627 & 584 & 597 & 624 & 582 & 584 & & \\
\hline $\mathrm{Yb}$ & 490 & 489 & 478 & 551 & 513 & 524 & 548 & 511 & 513 & 5,26 & 25,02 \\
\hline
\end{tabular}

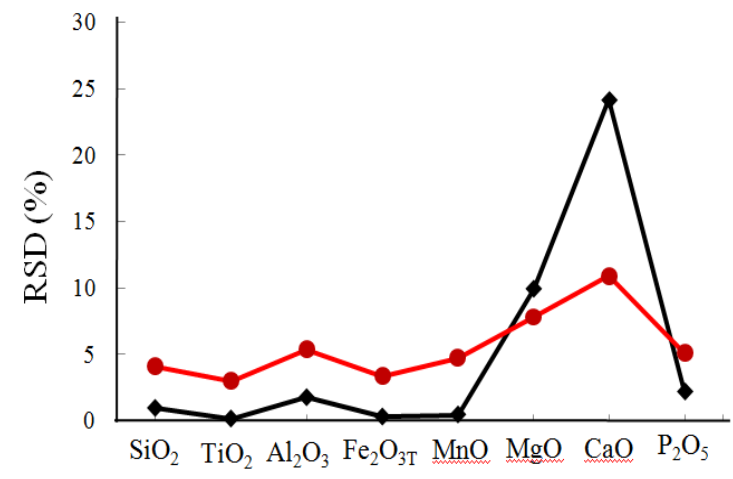

(a)

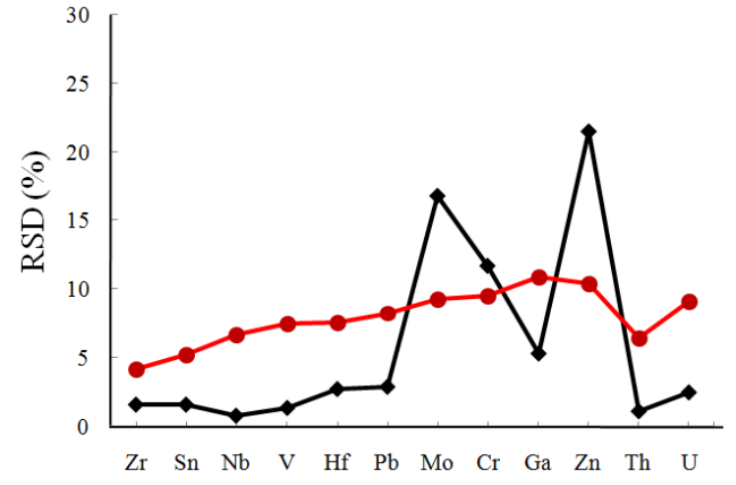

(b)

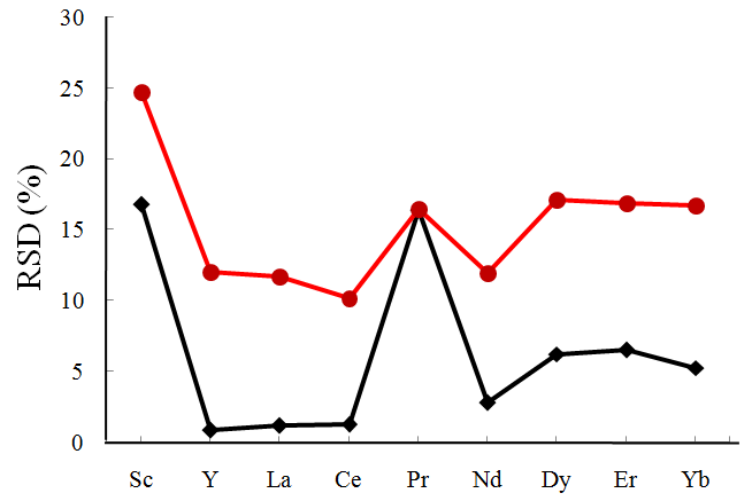

(c)

Gambar 6. Perbandingan RSD delapan kali pengulangan pengukuran terhadap RSDHorwitz a) Oksida Utama; b)

Unsur Jejak; dan c) Unsur Tanah Jarang. $\rightarrow$ adalah RSDanalisis, sedangkan $\bullet$ adalah 2/3 x RSDHorwitz. Berdasarkan konsep Horwitz maka hampir seluruh pengukuran analit dianggap presisi kecuali $\mathrm{MgO}, \mathrm{CaO}$, $\mathrm{Mo}, \mathrm{Cr}$, dan Zn. 


\section{Titanium dan Besi pada Limbah Timah}

Secara alamiah, timah dapat terdiri dari dua valensi, yaitu $\mathrm{Sn}^{2+}$ yang bersifat reduktif dan $\mathrm{Sn}^{4+}$ yang oksidatif (Chen dkk., 2013). Kebanyakan mineral pembawa timah dibentuk oleh $\mathrm{Sn}^{4+}$, yaitu kasiterit $\left(\mathrm{SnO}_{2}\right)$, stanit $\left(\mathrm{Cu}_{2} \mathrm{FeSnS}_{4}\right)$, malayait $\left(\mathrm{CaSnSiO}_{5}\right)$, dan mohit $\left(\mathrm{CuSnS}_{3}\right) . \mathrm{Sn}^{4+}$ dapat terikat pada mineral pembawa $\mathrm{Ti}$ dan $\mathrm{Fe}$, seperti titanit $\left(\mathrm{CaTiSiO}_{5}\right)$ dan magnetit $\left(\mathrm{Fe}^{2+} \mathrm{Fe}^{3+}{ }_{2} \mathrm{O}_{4}\right)$ sebagai pengganti baik $\mathrm{Ti}^{4+}$ maupun $\mathrm{Fe}^{4+}$ karena karakter isovalensinya (Chen $d k k$., 2013; Wang $d k k$., 2013; Kern $d k k ., 2018) . \mathrm{Ti}^{4+}$ pada titanit yang telah tergantikan seluruhnya oleh $\mathrm{Sn}^{4+}$ menghasilkan mineral malayait ( $\left.\mathrm{CaSnSiO}_{5}\right)$, sedangkan $\mathrm{Ti}^{4+}$ kemudian teroksidasi membentuk $\mathrm{TiO}_{2}$ seperti proses pada persamaan (5) dan (6) berikut:

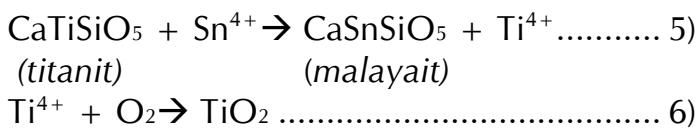

Titanium pada magma yang mengandung titanit akan semakin tergantikan oleh timah sepanjang proses evolusinya sehingga dapat menjelaskan kronologi beberapa granit pembawa timah dalam suatu wilayah (Wang $d k k ., 2013)$. Oleh sebab itu, keberadaan titanit dijadikan salah satu indikator granit yang berpotensi membawa timah seperti telah dilakukan di Hunan (Xie dkk., 2010) dan Nanling (Chen $d k k$., 2013). Penelitian lain juga menyebutkan bahwa konsentrat titanium memang dapat ditemukan sebagai produk samping penambangan timah (Gázquez $d k k$., 2014; Ahmadi $d k k$., 2016). Tingginya kadar $\mathrm{TiO}_{2} \quad(>50 \%)$ dan $\mathrm{Fe}_{2} \mathrm{O}_{3} \mathrm{~T} \quad(>22 \%)$ pada percontoh yang dipelajari (Tabel 1) dapat dipahami berdasarkan argumen-argumen di atas. Kemudian, melimpahnya jumlah produk samping berbentuk serupa di Nudur dapat menjadi indikasi bahwa titanit dan malayait terdapat bersama pada granit induk yang ditambang. Keterdapatan kedua mineral ini dapat diperjelas melalui studi petrografi.

Titanium berada dalam urutan kesembilan sebagai elemen paling melimpah pada kerak bumi (sekitar 0,6\%). Meski kelimpahannya lima kali lebih kecil dari besi ( $\mathrm{Fe}$ ), elemen ini seratus kali lebih melimpah dibandingkan dengan tembaga. $\mathrm{TiO}_{2}$ dianggap strategis karena dibutuhkan pada industri pesawat terbang, cat tembok, plastik, tinta, kertas, farmasi, tekstil, hingga makanan (Gázquez $d k k ., 2014)$. $\mathrm{TiO}_{2}$ dapat dipisahkan dari pengotornya melalui proses menggunakan klorida $\left(\mathrm{Cl}_{2}\right)$, asam sulfat $\left(\mathrm{H}_{2} \mathrm{SO}_{4}\right)$, dan mikroba (Jonglertjunya dan Rubcumintara, 2013; Ahmadi $d k k$., 2016). Penggunaan tungku busur listrik yang menghemat penggunaan elektroda dan konsumsi energi dapat memisahkan titanium dari pengotornya hingga mencapai tingkat ekstraksi sebesar 79,21\% (Supriyatna $d k k ., 2019)$. Oleh sebab itu, keberadaan $\mathrm{TiO}_{2}$ pada limbah timah di Nudur tentu dapat dijadikan peluang bisnis tersendiri bagi PT Timah dengan mengembangkan unit pengolahan dengan aplikasi teknis yang telah tersedia.

\section{KESIMPULAN DAN SARAN}

\section{Kesimpulan}

Berdasarkan konsep RSD <2/3 kali RSDHorwitz, maka hampir seluruh oksida utama pada hasil pengukuran dalam studi ini berkategori presisi kecuali $\mathrm{MgO}$ dan $\mathrm{CaO}$. Meskipun beberapa unsur jejak (Mo, $\mathrm{Cr}$, dan $\mathrm{Zn}$ ) tidak presisi, seluruh unsur tanah jarang terbukti memiliki derajat presisi tinggi berdasarkan teori Horwitz tersebut.

Produk samping penambangan timah di Nudur tersebut cukup ekonomis dengan kandungan $\mathrm{TiO}_{2}$ dan $\mathrm{Fe}_{2} \mathrm{O}_{3} \mathrm{~T}, \mathrm{Zr}, \mathrm{Ce}$, dan $\mathrm{Sn}$ yang tinggi, sehingga dapat dimanfaatkan selanjutnya oleh PT Timah. Terdapat indikasi awal bahwa titanit dan malayait hadir bersama pada granit induk pembawa timah di Nudur berdasarkan komposisi geokimia percontoh yang dipelajari.

\section{Saran}

Metode pemanfaatan XRF untuk pengukuran LTJ dapat dipertajam menggunakan analisis ICP-MS. Keterdapatan titanit dan malayait pada granit di Nudur mampu dikonfirmasi melalui studi petrografi.

\section{UCAPAN TERIMA KASIH}

Penulis mengucapkan terima kasih kepada Kepala Pusat Survei Geologi atas izin penggunaan data untuk publikasi ini. Kami 
sangat terbantu oleh PT Timah untuk masuk ke lokasi tambang di Nudur dan dalam menyelesaikan pekerjaan kami lainnya di Pulau Bangka. Ucapan terimakasih juga disampaikan kepada Dr. Purnama Sendjaja, S.T., M.T. atas bimbingannya mengenai geologi setempat serta Ir. Joko Subandrio, M.Si dan Verry Edi Setiawan, S.T. yang telah banyak membantu mengenai interpretasi geologis. Irfanny Agustiany S.Si., Citra Okta Hagia S.T., dan Indah Yuni Prasetyawati S.T. telah membantu dalam mengarahkan hasil uji laboratorium.

\section{DAFTAR PUSTAKA}

Ahmadi, E., Sereiratana, E. M., Rezan, S. A., Yeoh, F. Y., Ahmad Fauzi, M. N. dan Zhang, G. (2016) "Assessment of titanium carbide chlorination by statistical design," Materials Science Forum, 860, hal. 111-114. doi: 10.4028/www.scientific.net/MSF.860.111.

Ashraf, M. A., Maah, M. J. dan Yusoff, I. (2011) "Heavy metals accumulation in plants growing in ex tin mining catchment," International Journal of Environmental Science \& Technology, 8(2), hal. 401-416. doi: 10.1007/BF03326227.

Asmariani, Amriani dan Haslianti (2017) "Verifikasi metode uji lemak pakan buatan," FishtecH Jurnal Teknologi Hasil Perikanan, 6(1), hal. 92-96.

Chen, J., Wang, R., Zhu, J., Lu, J. dan Ma, D. (2013) "Multiple-aged granitoids and related tungsten-tin mineralization in the Nanling Range, South China," Science China Earth Sciences, 56(12), hal. 2045-2055. doi: 10.1007/s11430-013-4736-9.

Cobbing, E. J. (2005) "Chapter 5 Granites," Geological Society, London, Memoirs, 31(1), hal. $54-62$.

doi: 10.1144/GSL.MEM.2005.031.01.05

Frierdich, A. J., Hasenmueller, E. A. dan Catalano, J. G. (2011) "Composition and structure of nanocrystalline $\mathrm{Fe}$ and $\mathrm{Mn}$ oxide cave deposits: Implications for trace element mobility in karst systems," Chemical Geology, 284(1-2), hal. 82-96.

doi: 10.1016/j.chemgeo.2011.02.009.

Gázquez, M. J., Bolívar, J. P., Garcia-Tenorio, R. dan Vaca, F. (2014) "A review of the production cycle of titanium dioxide pigment," Materials Sciences and Applications, 05(07), hal. 441458. doi: 10.4236/msa.2014.57048.
Hamzah, Y., Mardhiansyah, M. dan Firdaus, L. N. (2018) "Characterization of rare earth elements in tailing of ex-tin mining sands from Singkep Island, Indonesia," Aceh International Journal of Science and Technology, 7(2), hal. 131-137. doi: 10.13170/aijst.7.2.8622.

Haq, M., Ahmad, N., Nasir, M., Jamal, Hafeez, M., Rafi, J., Zaidi, S. dan Haroon, W. (2018) "Carbon nanotubes (CNTs) in asphalt binder: Homogeneous dispersion and performance enhancement," Applied Sciences, 8(12), hal. 2651. doi: 10.3390/app8122651.

Harmita (2004) "Petunjuk pelaksanaan validasi metode dan cara perhitungannya," Majalah Ilmu Kefarmasian, 1(3), hal. 117-135.

Hunt, A. M. W., Dvoracek, D., Glascock, M. D. dan Speakman, R. J. (2015) "Major, minor and trace element mass fractions determined using ED-XRF, WD-XRF and INAA for three fireclay reference materials: č.137; č.138; and č.139," Journal of Radioanalytical and Nuclear Chemistry, 303(1), hal. 977-978. doi: 10.1007/s10967-014-3365-x.

Irzon, R. (2015) "Contrasting two facies of Muncung Granite in Lingga Regency using major, trace, and rare earth element geochemistry," Indonesian Journal on Geoscience, 2(1), hal. 23-33. doi: 10.17014/ijog.2.1.23-33.

Irzon, R. (2017) "Pengayaan logam berat Mn, Co, dan $\mathrm{Cr}$ pada laterit nikel di Kabupaten Konawe Utara, Provinsi Sulawesi Tenggara," Buletin Sumber Daya Geolog, 12(2), hal. 71-86. Tersedia pada: http://buletinsdg.geologi.esdm.go.id/index.ph p/bsdg/article/view/BSDG_VOL_12_NO_2_2 017_1.

Irzon, R., Syafri, I., Hutabarat, J., Sendjaja, P. dan Permanadewi, S. (2018) "Heavy metals content and pollution in tin tailings from Singkep Island, Riau, Indonesia," Sains Malaysiana, 47(11), hal. 2609-2616. doi: 10.17576/jsm-2018-4711-03.

Irzon, R., Kurnia, Sendjaja, P., Harisaputra, D. dan Baharuddin, B. (2019) "Pengaruh pelapukan terhadap kadar platina dan paladium nikel laterit Konawe Utara," Jurnal Teknologi Mineral dan Batubara, 15(2), hal. 97-108. doi: 10.30556/jtmb.Vol15.No2.2019.925.

Irzon, R. dan Abdullah, B. (2016) "Geochemistry of Ophiolite Complex in North Konawe, Southeast Sulawesi," EKSPLORIUM, 37(2), hal. 101-114. doi: 10.17146/eksplorium.2016.37.2.2868. 
Irzon, R. dan Kurnia (2014) “Optimasi teknik fire assay dan kondisi kupelasi untuk memperoleh komposisi fluks terbaik pada analisis kadar emas," Jurnal Geologi dan Sumberdaya Mineral, 15(1), hal. 55-62. Tersedia pada: http://jgsm.geologi.esdm.go.id/index.php/JGS M/article/view/70.

Irzon, R. dan Kurnia (2015) "Bahan standar internal dengan matriks stream sediments dari sungai berair payau dan tawar di daerah Pangandaran dan sekitarnya," Jurnal Geologi dan Sumberdaya Mineral, 16(2), hal. 67-77.

Irzon, R. dan Kurnia (2019) "Penajaman nilai acuan standar internal SS Pang 10 melalui uji banding laboratorium," Jurnal Standardisas, 21(2), hal. 125-134.

Jonglertjunya, W. dan Rubcumintara, T. (2013) "Titanium and iron dissolutions from ilmenite by acid leaching and microbiological oxidation techniques," Asia-Pacific Journal of Chemical Engineering, 8(3), hal. 323-330. doi: 10.1002/apj.1663.

Kern, M., Möckel, R., Krause, J., Teichmann, J. dan Gutzmer, J. (2018) "Calculating the deportment of a fine-grained and compositionally complex Sn skarn with a modified approach for automated mineralogy," Minerals Engineering, 116, hal. 213-225.

doi: 10.1016/j.mineng.2017.06.006.

Lin, L., Hu, Z., Yang, L., Zhang, W., Liu, Y., Gao, S. dan Hu, S. (2014) "Determination of boron isotope compositions of geological materials by laser ablation MC-ICP-MS using newly designed high sensitivity skimmer and sample cones," Chemical Geology, 386, hal. 22-30. doi: 10.1016/j.chemgeo.2014.08.001.

Margono, U., Supandjono, R. J. B. dan Partoyo, E. (1995) "Peta geologi lembar Bangka Selatan Sumatra." Pusat Penelitian dan Pengembangan Geologi, hal. 1.

Miao, Q., Hu, L., Wang, G. dan Wang, E. (2011) "Fabrication of excellent mechanical properties AZ31 magnesium alloy sheets by conventional rolling and subsequent annealing," Materials Science and Engineering: A, 528(22-23), hal. 6694-6701. doi: 10.1016/j.msea.2011.05.023.

Nadoll, P. dan Koenig, A. E. (2011) "LA-ICP-MS of magnetite: methods and reference materials," Journal of Analytical Atomic Spectrometry, 26(9), hal. 1872-1877.

doi: 10.1039/c1ja10105f
Ng, S. W.-P., Whitehouse, M. J., Roselee, M. H., Teschner, C., Murtadha, S., Oliver, G. J. H., Ghani, A. A. dan Chang, S.-C. (2017) "Late Triassic granites from Bangka, Indonesia: A continuation of the Main Range granite province of the South-East Asian Tin Belt," Journal of Asian Earth Sciences, 138, hal. 548561. doi: 10.1016/j.jseaes.2017.03.002.

Purwadi, I., van der Werff, H. dan Lievens, C. (2019) "Reflectance spectroscopy and geochemical analysis of rare earth element-bearing tailings: A case study of two abandoned tin mine sites in Bangka Island, Indonesia," International Journal of Applied Earth Observation and Geoinformation, 74, hal. 239-247. doi: 10.1016/j.jag.2018.09.006.

Supriyatna, Y. I., Kambuna, B. N. H., Trinopiawan, K. dan Putra, P. A. (2019) “Pengaruh variasi waktu dan reduktor pada peleburan titanium dari terak timah menggunakan tungku busur listrik," Jurnal Teknologi Mineral dan Batubara, 15(3), hal. 189-199. doi: 10.30556/jtmb.Vol15.No3.2019.1041.

Taufiq, A., Hutagaol, R. P. dan Pramono, U. (2011) "Metode alternatif analisis sulfur dalam solar dengan alat ICP-OES Optima 5300 Perkin Elmer," Jurnal Sains Natural Universitas Nusa Bangsa, 1(1), hal. 25-31.

Ubide, T., McKenna, C. A., Chew, D. M. dan Kamber, B. S. (2015) "High-resolution LA-ICPMS trace element mapping of igneous minerals: In search of magma histories," Chemical Geology, 409, hal. 157-168. doi: 10.1016/j.chemgeo.2015.05.020.

Usman, E. (2016) "The geochemical characteristic of major element of granitoid of Natuna, Singkep, Bangka and Sibolga," Bulletin of the Marine Geology, 30(1), hal. 45. doi: 10.32693/bomg.30.1.2015.74.

Wang, R. C., Xie, L., Chen, J., Yu, A., Wang, L., Lu, J. dan Zhu, J. (2013) "Tin-carrier minerals in metaluminous granites of the western Nanling Range (southern China): Constraints on processes of tin mineralization in oxidized granites," Journal of Asian Earth Sciences, 74, hal. 361-372. doi: 10.1016/j.jseaes.2012.11.029.

Xie, L., Wang, R.-C., Chen, J. dan Zhu, J.-C. (2010) "Mineralogical evidence for magmatic and hydrothermal processes in the Qitianling oxidized tin-bearing granite (Hunan, South China): EMP and (MC)-LA-ICPMS investigations of three types of titanite," Chemical Geology, 276(1-2), hal. 53-68. doi: 10.1016/j.chemgeo.2010.05.020. 
